\title{
Analysis on the Relationship between the RMB Internationalization and the Capital Account Openness
}

\author{
Qinglong Zhang \\ Business School \\ University of Shanghai for Science and Technology \\ Shanghai , China \\ E-mail: qlzhang71@sina.com
}

\begin{abstract}
The benign interaction between the Renminbi(RMB) internationalization and the capital account openness is conducive to steadily push forward the RMB internationalization. The paper studies the relationship between the RMB Internationalization and the capital account openness from three aspects of the RMB free exchange, liberalization of capital account transactions and RMB import $\&$ export. The conclusions are as follows: the RMB free exchange is not the premise of RMB internationalization, and RMB internationalization doesn't need to request RMB to be fully convertible currency; the RMB internationalization can be promoted without the liberalization of capital account transactions; the gradual liberalization policy should be taken for the number and channel of the RMB import \& export.
\end{abstract}

Keywords- RMB Internationalization capital account openness RMB export-import

\section{INTRODUCTION}

The RMB internationalization refers to the economy process in which RMB crosses borders, circulates abroad, and becomes the payment means, account unit and storage method generally accepted in the world. The capital account openness refers to "removing all kinds of restrictions imposed on the capital account, including currency convertibility, foreign payment and transactions". By definition, the capital account openness includes the deregulation of the capital transactions, the freedom of currency flowing across borders and the relaxation of the currency exchange controls. But it's important to note that the capital account openness does not mean that the capital account business is laissez faire. From the Annual Report of Exchange Arrangements and Exchange Limits of the International Monetary Fund(IMF), there is a certain degree of capital account controls in almost all countries. As a result, the capital account openness does not rule out the management of capital account. The paper studies the relationship between the RMB internationalization and the capital account openness from three aspects of the RMB free exchange, liberalization of capital account transactions and $\mathrm{RMB}$ import \& export.

\section{THE RMB INTERNATIONALIZATION AND THE RMB FREE EXCHANGE}

The concept of the RMB internationalization is different from that of the RMB free exchange. The judgment standard of the former is the extent to which RMB is treated as the payment means, account unit and storage method in the world, while the latter has two judgment standards, one is the theoretical standard, the other is the criterion set by IMF. First, in theory, the RMB free exchange refers to all kinds of currency conversions without limits set by the government, and holders can be free to convert RMB into international currencies. It includes the currency free exchange both under the current account and under the capital account. Second, according to the regulation of IMF, for those countries whose currencies are freely convertible, the currency exchange under the current account should be free, and the currency exchange under the capital account should also be free, but ways to convert can be limited in a certain degree. Which shows that on the one hand, IMF advocates the currency free exchange under the capital account, on the other hand, member states may, when necessary, implement the restrictions on the currency exchange in a certain degree. Therefore, in accordance with the provisions of IMF, the RMB free exchange should include the free exchange under the current account and conditional convertibility under the capital account, and should be called as the basically free exchange of RMB. Next, the paper analyzes the relationship between the RMB internationalization and the RMB free exchange from the following several aspects.

\section{A. The importance of the RMB free exchange}

The RMB internationalization can be divided into two stages, that is the primary stage and the advanced stage. In the primary stage, the RMB internationalization does not necessarily need the fully free exchange of RMB. From China's reality, in the current situation, the process of the RMB internationalization has started, but the RMB is still not fully convertible under the capital account, which shows the process of the RMB internationalization may be independent of the process of RMB convertibility to some extent. In addition, as the influencing factors of the RMB internationalization are different from that of the RMB free exchange, the RMB internationalization process may be inconsistent with the RMB convertibility process. 
However, accompanied by the currency internationalization process, a country's financial regulation, especially the foreign exchange control, will continue to relax. The relaxation of foreign exchange control means the local currency changes gradually from the inconvertible currency to the convertible currency under the current account and under the capital account, and eventually becomes the fully convertible currency. As one of the conditions of the currency internationalization, the currency free convertibility can accelerate the process of the currency internationalization. Therefor, the RMB free exchange is one of the conditions of the RMB internationalization, but it is not the premise of the RMB internationalization.

\section{B. The Difference of the Conditions}

In some extent, the RMB free convertibility can be decided by the government policy, and implemented in a short time. But the RMB internationalization is mainly the result of market selection, and It is based on China's comprehensive competitiveness including economic strength, political power and military power, and it is after a long-term development process that can come true. Without sufficient conditions, even if it is a freely convertible currency, RMB will not necessarily become a international currency. Which has been proved by the monetary history of many countries in the world. At the beginning of 1995, all industrialized countries realized the currency free convertibility under the capital account. At the same time, developing countries are gradually relaxing restrictions on the capital account convertibility. By 1996, developing countries and regions, such as petroleum exporting countries in the Middle East, Singapore, Hong Kong, panama, Libya and Indonesia, also realized the currency free convertibility under the capital account. But among those currencies, there are very few currencies to really become an international currency.

\section{The Nature of the RMB Free Exchange}

At present, there is not a completely and freely convertible currency in the world. Strictly speaking, even in the those countries with a fully freely convertible currency, there still exists a variety of controls over the currency conversion under the current account and the capital account. The "currency free convertibility" can only be called as the basically free exchange, and the fullly free convertibility is merely a theoretical concept. Therefore, even if it is a international currency, the currency is not necessarily the fullly free convertibility. If the free convertibility refers to the basically free convertibility, a completely international currency must be a freely convertible currency.

From what has been discussed above, the RMB free convertibility is not the premise of RMB internationalization, and the RMB internationalization request the basically free convertibility as a condition. In the RMB internationalization process, we should neither be passive towards the RMB internationalization because of the RMB's being not freely convertible, nor speed blindly up the pace of the RMB free convertibility in order to promote the RMB internationalization process. In the process of pushing the RMB internationalisation, we should follow the objective economic laws in order to reduce the negative impact of the RMB internationalization on the national economy.

\section{RMB INTERNATIONALIZATION AND CAPITAL ACCOUNT TRANSACTIONS LIBERALIZATION}

The capital account transactions refer mainly to the international transactions arising from the international direct investment and indirect investment under the capital account. With the RMB internationalization process, the controls over capital account transactions will be gradually relaxed. RMB internationalization process is bound to accompany with the liberalization of capital account transactions. But the liberalization of capital account transactions is not the inevitable premise of the RMB internationalization. Which has been proved by the development history of some international currencies. In the 1970s, The German government does not support the mark's internationalization, implements the regulation on the non-residential capital transaction, and limits the international financing by capital controls. Even so, the Euromark market still developed. The mark internationalization was mainly not because of the liberalization of capital account transactions, but because of the competitive trade goods and the huge share German held in the European trade. And it is the German economy scale and its trade position that make the mark become a widely accepted international currency in Europe.

Once a currency has become the international currency, the restrictions on capital account transactions do not cause a decline in the international status of the currency. In the following, the paper takes the British pound and the U.S. dollar as an example to illustrate this problem.

The British pound is a good example. During the first world war, the British government and the bank of England controlled the issue of foreign bonds, which hindered the long-term capital transactions, but it didn't destroy the international currency status of the pound, and other countries still use the pound for the trade financing and official reserves. Which is largely due to the British commodity market size and share in the world trade at that time. Particularly, in the 1930s, sterling area countries could benefit from exports to the UK, and The UK market was very important for them. Therefore, it was the importance of the British market that maintains the international status of the pound, which was not weakened by the temporary restrictions on capital account transactions.

The U.S. dollar is another example. In the 1960s, although the United States controlled the international loan and investment, due to the development of the eurodollar market, the dollar's international finance didn't decline, and its international status is not weakened by that. At that time, the U.S. is the largest importer and exporter, and has technical advantages not only in manufacturing business, but also in the management and financial business in the world, which was the important factors to maintain the international status of the U.S. dollar. In other words, it was the U.S. economy size and the competitiveness in real transactions that supports the U.S. dollar's international status which was not weakened by the temporary restrictions on capital account transactions. 
Even today, several major international currency countries donn't fully open capital account transactions. For example, there are still many restrictions on capital account transactions in the U.S.. The U.S. goverment implements some restrictions on capital account transactions for the list of countries such as Cuba, Iran, north Korea, Iraq, Libya, Sudan, Yugoslavia, etc, and for the important items which will likely influence the U.S. economy sovereignty or investor rights and interests. For example, in terms of securities investment, the U.S. government carries out strict controls on buying securities of these industries such as nuclear energy, ocean, communications, air freight and so on by non-residents, and also on foreign mutual funds (mainly offshore fund)in order to protect the rights and interests of investors in the U.S.. In terms of direct investment, the U.S. Government will suspends or prohibits the transactions by which the foreign capital acquires a controlling stake and could threaten the national security. The investment involving the bank ownership is constrainted by the federal and state banking regulations. In addition, there are also different restrictions on buying land by foreigners in some states.

Contrary to the above analysis, even if there is the capital account openness and transactions liberalization in a country, its currency will not necessarily become a international currency. In many developed countries and some developing countries and regions, the capital account transactions are highly liberalization, but their currencies are not the international currency. According to the statistics from IMF, from 1975 to 1997 , the number of countries with the capital account liberalization increased from 23 to 53. Among those, only few currencies are the international currency.

\section{RMB INTERNATIONALIZATION AND RMB IMPORT \& EXPORT}

The RMB internationalization will lead to the RMB foreign circulation, which the monetary authorities can't control, and it will weaken the effect of monetary policy.

Therefore, we should take a gradually opening-up policy and carefully plan the size and policy of . Next, the paper analyzes the problem of the RMB import \& export from the two stages of the RMB internationalization including the primary stage and the advanced stage.

\section{A. The Primary Stage of the RMB Internationalization}

In the primary stage of the RMB internationalization, we should reduce the impact of the RMB foreign circulation through the restriction on the size of the RMB foreign circulation. At this stage, the RMB international status is not high, the export size should be less as far as possible. And we should improve the international reputation and status of RMB mainly through the enhancement of comprehensive national strength and competitiveness, gradually increasing the degreee of the RMB internationalization and promoting the RMB functions of the payment means and the account unit in the international trade and investment.

From the Angle of the RMB export, at the present stage, we may export RMB through the following ways. One is through bilateral or multilateral currency swap. Up to now, the people's bank of China has signed currency swap deals respectively with Argentina, belarus, Indonesia, Malaysia, South Korea, Hong Kong, Japan, Britain and so on. We may export RMB on the basis of the currency swap. The other is through the trade deficit. That is, we may use RMB to pay the trade deficit. For a long time, China has maintained a trade deficit with some east Asian countries and regions, especially Hong Kong and the association of southeast Asian nations (ASEAN). And the establishment of the ChinaASEAN free trade area has provided a realistic foundation for the RMB export through the trade deficit. The third is to gradually let Chinese enterprises make the overseas investment directly with the RMB.

From the Angle of the RMB import, at present, in order to make foreign holders have the confidence for holding RMB and maintain RMB value stability, we must solve the problem of the orderly flow and the overseas use of the offshore RMB.

First of all, we may establish channels of RMB crossborder remittances through bilateral cooperation of central banks and commercial banks at home and abroad. At the same time, we may also allow offshore RMB holders to carry a certain amount of RMB in notes for the entry and exit. Through the above measures, we can establish effective channels of the offshore RMB backflow.

Second, we may allow overseas backflow RMB to buy goods in China, government bonds, and make direct investments to China to solve the problem of the use of the return RMB. But at present, we should not support the requests of the return $\mathrm{RMB}$ for exchanging international reserves, buying financial assets such as stocks and funds.

Third, we should solve the problem of the RMB use outside. At this stage, we may absorb offshore RMB deposits through China's bank branches located overseas. But we should limit the RMB overseas loans. However, with the China's financial fragility improved, we may gradually relax this restriction. it would be best that we first polit a small size of RMB loans in Hong Kong, and then gradually expand the loan size after accumulating experiences.

However, for security, we must monitor effectively the cross-border flow of RMB, and put it into the formal financial system, to achieve the RMB's orderly cross-border flow. This can be realized both through the multi-level and comprehensive cooperation between the monetary authorities and commercial banks at home and abroad, and through the monitoring of the customs and bank statements. the RMB's orderly cross-border flow is conducive to improve the effectiveness of the monetary policy, and reduce the adverse impact of the RMB cross-border flows on the economy.

\section{B. The Advanced Stage of the RMB Internationalization}

In the advanced stage of the RMB internationalization, the RMB international status has significantly been improved. At this time, we may further expand the scale of the RMB export through the trade deficit and capital export on the one hand, and further relax the restrictions on the RMB investments at home and abroad on the other hand, in order to make RMB becomes the payment means, account unit and storage method generally accepted in the world, and realize 
the comprehensive internationalization of RMB in various functions.

\section{CONCLUSION}

To sum up, there are both connection and difference between the RMB internationalization and the capital account openness, and each has its own operating rules. We can't determine the process of opening the capital account according to the process of RMB internationalization, but should gradually and orderly promote the capital account openness with maintaining China's financial security and healthy development as the basic principle. The capital account openness is not designed for the RMB internationalization, but for effectively developing China's economy, improving the comprehensive national strength. When the RMB internationalization goes into the higner stage, and the preconditions of the capital account openness have been met, we may appropriately speed up the process of the capital account openness, in order to promote the RMB internationalization. Therefor, we should effectively combine the capital account openness with the RMB internationalization, to make the two promote each other and form benign interactive.

\section{REFERENCES}

[1] The international monetary fund. The exchange arrangements and exchange limit[M]. Beijing: China financial publishing house, 2000, (10) : 892-893.

[2] Jiang Boke. Capital account openness research: based on the analysis of the internal and external equilibrium[J]. Journal of international financial research, 2004, (4) : 16 - to 18.

[3] JiChuan yuan zhong. Financial defeat[M]. Beijing: China youth publishing house, 2000:163.

[4] jing xuecheng. Theory of basic convertibility of RMB[J]. Journal of finance and economics, 2000, (8) : 28-33.

[5] Mundell. Mundell essays in economics[C]. China financial publishing house, 2003, 168-160.

[6] Wu Nianlu. Theory of RMB convertibility and internationalization [J]. Journal of international financial research, 2009, (11) : 4-5.

[7] Blinder. S. A. The Role of the Dollar as an International Currency [J] . Eastern Economic Journal , 1996, 22 (2) .

[8] Hartmann, P.. Currency Competition and Foreign Exchange Markets : The Dollar, the Yen and the Euro[M]. Cambridge: Cambridge University Press.1998.

[9] Ministry of Finance. Internationalization of Yen for the Twenty-First Century: Japan's Response to Changes in Globle Economic and Financial Environments[R]. Tokyo: Ministry of Finance, Council on Foreign Exchange and Other Transactions, 1999. 